\title{
İlk Halka Arzda Düşük Fiyatlama Seviyesi Zamanla Değişiyor Mu? Borsa İstanbul Üzerine Bir Araştırma ${ }^{1}$
}

İbrahim Korkmaz KAHRAMAN ${ }^{2}$ Ender COŞKUN ${ }^{3}$

\begin{tabular}{lcc}
\hline $\begin{array}{c}\text { Geliş Tarihi/ Received } \\
13 / 09 / 2019\end{array}$ & Kabul Tarihi/ Accepted & Yayın Tarihi/ Published \\
$14 / 11 / 2019$ & $25 / 01 / 2020$ \\
\hline Citation/Atıf: Kahraman, İ., K. Ve Coşkun, E., (2020), İlk Halka Arzda Düşük Fiyatlama Seviyesi \\
Zamanla Değişiyor Mu? Borsa İstanbul Üzerine Bir Araştırma, Atatürk Üniversitesi İktisadi ve İdari \\
Bilimler Dergisi, 34(1):145-167, DOI: $10.16951 /$ atauniiibd.620084 & \\
\hline
\end{tabular}

Öz: Bu çalışmada Türkiye'de ilk halka arzı gerçekleşen 320 şirketten oluşan geniş bir örneklem üzerinde düşük fiyatlamanın varlığı ve düşük fiyatlama seviyesinin zaman içerisinde değişip değişmediği araştırılmaktadır. Farklı anormal getiri hesaplama yöntemlerinin kullanıldığı çalışmada, düşük fiyatlamanın varlığı tespit edilmiştir. Yapılan analizlerde ilk halka arzlarda ilk üç gün boyunca istatistiksel olarak anlamlı bir şekilde anormal getiri elde edildiği ve bu dönemde halka arz fiyatına göre ortalama \%10.2 kümülatif anormal getiri elde edildiği saptanmıştır. Ancak daha sonraki günlerde anormal getirinin negatife döndüğü ve kümülatif anormal getirinin örneğin beş ile on beşinci günler arasını kapsayan dönemde -\%2.72 olarak gerçekleştiği ve bu dönemde istatistiksel olarak anlamlı negatif getirinin ortaya çıktığı görülmektedir. Çalışmada ayrıca halka arzda anormal getirinin diğer bir ifade ile düşük fiyatlandırma seviyesinin zaman içerisinde azaldığ 1 , örneğin 1993-2000 yılları arasında halka arz edilen 125 şirket için ilk gün anormal getiri \% 8.8 iken 2002-2015 yılları arasında halka arz edilen şirketler için bu oranın \% 5.9'a düştüğü ve bu düşüşün istatistiksel açıdan anlamlı olduğu tespit edilmiştir. Bu durum yıllar itibari ile finansal piyasalarda ve halka arz süreçlerinde yaşanan gelişmelerin ilk halka arzda düşük fiyatlamayı azaltıcı yönde etkilediğini ancak düşük fiyatlamanın halen varlığını devam ettirdiğini göstermektedir.

Anahtar Kelimeler: İlk Halka Arz, Düşük Fiyatlama, Borsa İstanbul

Does Underpricing Level Vary With Time? An Ipo Research On Borsa Istanbul

Abstract: This research paper investigates the presence of underpricing and the timevariability of the level of underpricing over a broad sample comprising of 320 companies which have gone through initial public offerings (IPOs) in the Turkish stock market. Various methods employed in estimating the abnormal returns attest the validity of underpricing. Through our analysis it is determined that statistically significant abnormal returns, $10.2 \%$ with respect to IPO price on average, during the first three days after IPO is initialized are attainable. Yet, within the subsequent days these abnormal returns turn out to be negative, an example to this end is the observed $-2.72 \%$ cumulative

${ }^{1}$ Bu çalışma, Doç. Dr. Ender COŞKUN danışmanlığında Pamukkale Üniversitesi Sosyal Bilimler Enstitüsünde yürütülen "İlk Halka Arzda Düşük Fiyatlama Olgusu ve Borsa İstanbul'da Düşük Fiyatlamanın Belirleyicileri” başlıklı yüksek lisans çalışmasından türetilmiştir.

${ }^{2}$ Öğr. Gör. Pamukkale Üniversitesi, Çal Meslek Yüksekokulu, Muhasebe ve Vergi Uygulamaları Bölümü, https://orcid.org/0000-0001-5083-3586

${ }^{3}$ Doç. Dr. Pamukkale Üniversitesi, İktisadi ve İdari Bilimler Fakültesi, İşletme Bölümü, https://orcid.org/0000-0003-2833-4363 
Ilk Halka Arzda Düşük Fiyatlama Seviyesi Zamanla Değişiyor Mu? Borsa İstanbul Üzerine Bir Araştırma

abnormal return in the five to fifteen days' period, which is also found to be statistically significant. Moreover, we also report the decrease in the level of underpricing through time, i.e. while the first day abnormal return is 8.8\% for the 125 companies which have gone public in 1999-2000, corresponding rate falls to 5.9\% for IPOs during 2002-2015. Taking this decrease in underpricing level, which is also determined to be statistically significant, into consideration, we conclude that the developments in financial markets and IPO processes negatively effects IPO underpricing, but currently underpricing keeps its presence in Borsa Istanbul.

Keywords: IPO, Underpricing, Borsa Istanbul

\section{Research Problem}

\section{EXTENDED SUMMARY}

The results obtained from the studies on underpricing in the initial public offering (IPO), in other words abnormal return, may vary according to the countries, the research period, the number of companies used in the research and the calculation method. The aim of this study is to investigate by creating a comprehensive sampling in Turkey, existence of IPO underpricing and whether underpricing level is changed over time by using different methods of calculating abnormal returns.

\section{Research Questions}

In our study, a large data set was created and the question of whether there is a underpricing anomaly in Borsa Istanbul was answered using different abnormal return calculation methods.

In this study it is also examined whether the developments in the markets (such as the increase over time in the knowledge and experience of underwriters firms, investors and public offering companies and the improvement of the IPO processes) affected the low pricing level. For this purpose, in our study moving average abnormal returns were calculated by creating an equal number of subsamples and it was investigated whether the low pricing level changed over time.

\section{Literature Review}

The existence of low pricing in initial public offerings has been investigated in many countries and findings on the existence of low pricing in markets in general have been obtained (Ljungquist, 1997; Pham et al., 2003; Kooli and Suret, 2004; Dell'acqua et al., 2015). However, when the results are compared, it is observed that first-day abnormal returns or first-day returns may vary according to countries, the selection of the sample period, or the number of companies used in the sample. For example, Aggarwal and Rivoli (1990) determined first day adjusted returns as $10.67 \%$, Ritter (1991) determined first day returns as $14.30 \%$, and Ritter and Welch (2002) determined first day returns as $18.8 \%$.

In Turkey, an average abnormal return on the first day was determined as $12.2 \%$ in the study conducted by Kıymaz (1996). Aktaş et al., (2003) and Elmas (2013) have also found that low pricing exists. Teker and Ekit (2003) determined the first day return as $7 \%$, adjusted according to the market model. In one part of the studies, the initial public offering price and the return obtained according to the closing price of the first day were calculated without any correction according to the market return (Durukan, 2002; Dağlı ve Kurtaran, 2008; Oran et al., 2013). 


\section{Methodology}

In this study, the abnormal return performance of 320 companies whose IPO took place during the 22-year period spanning 1993-2015, covering the first twenty trading days is examined.

The initial public offering prices of the shares and the closing prices on the first trading day were used to calculate the return on the first day. Abnormal return is calculated by taking the difference of the calculated first day return according to the return of the market on the day the stock is first traded $\left(\mathrm{AR}_{\mathrm{T}}\right)$ and taking the difference between the issuance date of the share and the date of the first transaction $\left(\mathrm{AR}_{\mathrm{D}}\right)$.

In addition, abnormal returns were calculated according to the estimated returns according to the market model $\left(\mathrm{AR}_{\mathrm{P}}\right)$, and the companies with missing data were excluded from the sample and a sub-sample was created for 265 companies. In the calculation of abnormal return according to market model, the expected return of the stock is determined $\left(\hat{R}_{i, t}\right)$ and the difference between expected return and actual return is defined as abnormal return. In this method, the return of BIST 100 index is used for the return of the market. In the calculation of $A_{P}$, two separate time windows were created as the first 20 trading days after the public offering and 200 trading days after 20 trading days. According to the market model, alpha and beta coefficients were calculated in the second period of 200 trading days and the expected returns of the stocks for the first period of 20 trading days were calculated. For this sampling the mean $\mathrm{AR}_{\mathrm{T}}$ and $\mathrm{AR}_{\mathrm{D}}$ values were also calculated.

In our study, the companies were also aligned according to the public offering dates and abnormal returns were calculated on the basis of the moving average for the samples of 125 companies. Accordingly, the first group consists of 125 public offering companies between February 1993 and July 2000, while the second group was formed by excluding the first 15 companies starting from February 1993 and taking the first 15 public offering companies after July 2000 and again based on a sample of 125 companies. This process was continued until 2015 and the average first day abnormal returns were calculated for a total of 11 sub-samples.

\section{Results and Conclusions}

For the initial sample of 320 companies, $\mathrm{AR}_{\mathrm{D}}$ and $\mathrm{AR}_{\mathrm{T}}$ is calculated as $6.6 \%$ and $7.3 \%$ respectively. The abnormal return $\left(\mathrm{AR}_{\mathrm{P}}\right)$ is calculated as $7.2 \%$ according to the market model for the sample of 265 companies. The mean $\mathrm{AR}_{\mathrm{T}}$ and $\mathrm{AR}_{\mathrm{D}}$ values are calculated for the same sample as $7.2 \%$ and $6.4 \%$ respectively.All these rates indicate a non-zero return at a statistically significant $1 \%$ level, in other words, a strong presence of low pricing in companies that go public. It was determined that negative returns occurred on the eleven days of the sixteen day period until the fifth day and after the twentieth day, and some of these returns were statistically significant. Through our analysis it is determined that statistically significant abnormal returns, $10.2 \%$ with respect to IPO price on average, during the first three days after IPO is initialized are attainable. Yet, within the subsequent days these 
İlk Halka Arzda Düşük Fiyatlama Seviyesi Zamanla Değişiyor Mu? Borsa İstanbul Üzerine Bir Araştırma

abnormal returns turn out to be negative, an example to this end is the observed $2.72 \%$ cumulative abnormal return in the five to fifteen days' period, which is also found to be statistically significant. This condition shows that the abnormal returns that occurred in the first days were realized by the investors later on.

In addition, in this study companies are listed according to public offering dates and abnormal returns are calculated on the basis of moving average. According to this, it was determined that abnormal return was $8.8 \%$ for 125 companies that offered IPO between February 1993 and July 2000, which decreased in time and $5.9 \%$ for last group of 125 companies offered IPO between February 2002 and May 2015. It was concluded that the averages of these two groups were statistically different at $10 \%$ significance level. Taking this decrease in underpricing level, which is also determined to be statistically significant, into consideration, we conclude that the developments in financial markets and IPO processes negatively effects IPO underpricing, but currently underpricing keeps its presence in Borsa Istanbul.

\section{Giriş}

Şirketler ortaya çıkan ilave sermaye ihtiyaçlarını halka arz yoluyla pay senetlerini satarak karşılamayı bir finansman alternatifi olarak değerlendirmektedir. $\mathrm{Bu}$ bağlamda ilk halka arz halka kapalı şirketlerin ilk kez sermaye piyasalarını kullanarak sermaye artırma yoluyla fon temin etmelerini ifade etmektedir (Carter ve Manaster, 1990: 1045). Halka arz sürecinde şirketler bazı maliyetlere katlanmaktadır ve bu maliyetlerin bir kısmı halka arz sürecinde pay senedinin fiyatının düşük belirlenmesinden kaynaklanan dolaylı maliyetlerden oluşmaktadır. Düşük fiyatlama diğer bir ifade ile ilk halka arzda ortaya çıkan anormal getiri Carter ve Manaster (1990) tarafından "menkul kıymetlerin halka arz fiyatı ile ikincil piyasadaki ilk işlem günü oluşan fiyat arasındaki farkın kabul edilebilir bir risk priminin gerektirdiği farktan daha büyük olması" olarak tanımlanırken Ibbotson vd., (1988) tarafından "halka arz sürecinde oluşan halka arz fiyatından alım yapan yatırımcıların halka arz sonrası ilk işlem günü kapanış fiyatından satış yapması durumunda elde edecekleri getiri” olarak tanımlanmaktadır. Bu çerçevede düşük fiyatlama ile ilgili temel alınacak tanımlamaya göre ilk halka arzda hesaplanacak anormal getiri farklılaşabilmektedir. İlk halka arzda düşük fiyatlamanın, diğer bir ifade ile yatırımcılar açısından ilk halka arzda anormal getirinin varlığı birçok ampirik çalışmada tespit edilmiştir (Aggarwal ve Rivoli, 1990; Durukan, 2002; Kıymaz, 1996; Michaely ve Shaw, 1994; Otlu ve Ölmez, 2011; Ritter, 1984; Ünlü ve Ersoy, 2008).

Carter ve Manaster (1990) halka açılan şirketler için maliyetli bir durum olan düşük fiyatlamanın birçok çalışmada tespit edilmiş olmasının, halka açılan şirketlerin ve aracı kurumların bilerek düşük fiyatlamaya gittiklerinin göstergesi olduğunu ileri sürmektedir. Düşük fiyatlamanın ortaya çıkmasına neden olan çeşitli faktörler bulunmaktadır. (Baron, 1982; Carter ve Manaster, 1990; Rock, 1986) halka arzda rol alan taraflar arasındaki asimetrik bilginin, (Allen ve Faulhaber, 1989; Ritter, 1984) sektör ve piyasa yapısının, (Logue, 1973; Tınıç, 1988) aracı kurumun 
gücü ve risk algısının, Booth ve Smith (1986) halka arz olunan şirketin geleceği hakkındaki belirsizliğin büyüklügünün halka açılan şirketlerin pay senetlerinin düşük fiyatlanmasına yol açabileceğini ileri sürmüştür.

İlk halka arzda düşük fiyatlama üzerine yapılan çalışmaların kısa dönem ve uzun dönem fiyat performansı perspektifinden konuyu ele aldığı görülmektedir. İlk halka arzların fiyat performanslarına ilişkin çalışmaların sonuçları genel olarak, kısa dönemde piyasa getirisinin üzerinde anormal getiri sağlandığ fakat uzun dönemde elde edilen bu getirinin kaybolduğunu göstermektedir Aggarwal ve Rivoli (1990). Türkiye'de yapılan çalışmalarda da benzer bulguların elde edildiği görülmektedir (Kiymaz, 2000; Teker ve Ekit, 2003).

Çalışmamızın amaçlarından biri kısa dönemde Borsa İstanbul'da anormal getirinin var olup olmadığ yönünde daha önceki çalışmalarda elde edilen bulguları geniş bir örneklem seti kullanarak test etmektir. Halka açılan şirket sayısının artması dolayısı ile analize dâhil edilen şirket sayısının artışı, yapılan istatistiki testlerden elde edilen sonuçların güvenilirliğini de artıracaktır. Bu kapsamda 320 ilk halka arz araştırmaya dâhil edilmiş ve anormal getiri farklı hesaplama yöntemleri kullanılarak hesaplanmıştır. Bu açıdan çalışmanın amaçlarından biri de daha önceki çalışmalarda tespit edilen anormal getirinin farklı hesaplama yöntemlerine duyarlılığının test edilmesidir. Anormal getiri hesaplama yaklaşımındaki farklılıkların tespit edilen "anormal getiriyi" ne ölçüde etkilediği çalışmamızda cevabı aranan sorulardan biridir. Çalışmamızın bir diğer amacı ise anormal getirinin zaman içerisinde değişip değişmediğini ortaya koymaktır. (Allen ve Faulhaber, 1989; Ritter, 1984), sektör ve piyasa yapısının, Booth ve Smith (1986) şirket geleceği açısından ortaya çıkan belirsizliklerin anormal getiriyi etkilediğini ileri sürmektedir. Dolayısıyla yaklaşık 22 yıllık bir dönem içerisinde anormal getiri davranışının nasıl değiştiği önemli bir araştırma sorusu olarak karşımıza çıkmaktadır. Daha önce yapılan çalışmalarda dönemlerin farklılığı, örneklemlerin farklılığı bu konuda somut bir gözlem yapmayı engellemektedir. Çalışmamızda eşit sayıda alt örneklemler oluşturularak zaman içerisinde anormal getirinin değişip değişmediği, diğer bir ifade ile sermaye piyasalarında yaşanan gelişme seyrinin anormal getirini üzerinde etkisinin olup olmadığı test edilmektedir.

\section{Literatür Özeti}

İlk halka arzı gerçekleşmiş olan pay senetlerinin kısa dönem fiyat performansı üzerine yapılmış uluslararası çalışmalardan bazıları Tablo 1'de özetlenmiştir. Kısa dönem fiyat performansının geniş bir örneklem çerçevesinde incelendiği temel çalışmalardan biri Aggarwal ve Rivoli (1990) tarafından yapılan çalışmadır. 1,598 şirketten oluşan örneklemin kullanıldığ bu çalışmada ortalama düzeltilmiş getiriler birinci gün için $\% 10.67$, ilk yirmi gün için $\% 10.83$ ve yüz işlem günü için $\% 11.17$ bulunmuştur. Satın al ve tut yöntemine göre ilk gün kapanış fiyatından satın alan ve 250. gün sonunda pay senetlerini satan yatırımcının ise -\%13.73 getiri elde ettiğinin tespit edildiği çalışmada bu sonuçların düşük fiyatlamanın kısa dönemde geçerli olduğu, uzun dönemde bu etkinin ortaya çıkmadığına işaret ettiği vurgulanmaktadır. 
İlk Halka Arzda Düşük Fiyatlama Seviyesi Zamanla Değişiyor Mu? Borsa İstanbul Üzerine Bir Araştırma

Benzer bir dönemde ve 1,526 şirket üzerine yapılan bir diğer çalışmada ise Ritter (1991) ilk gün getiriyi \%14.30 olarak hesaplamıştır. Daha kısıtlı bir örneklemde Aggarwal (2000) tarafindan 1997 yılında halka arzı gerçekleşen 114 şirket için yapılmış çalışmada ortalama ilk gün ham getiri $\% 16.22$ ve piyasaya göre düzeltilmiş ilk gün getiri de \%15.82 bulunmuştur. ABD'de yapılan diğer bir çalışmada Barry ve Jennings (1993) 1988 ile 1990 yılları arasında ilk halka arzı gerçekleşen 229 pay senedinin kısa dönem getiri performansı incelemiştir. İlk gün açılış getirisi ve gün içi getiri olmak üzere iki hesaplamanın yapıldığ çalışmada, ihraç zamanında alım yapıp ilk gün satım yapan yatırımcılar mı yoksa gün içinde alım satım yapan yatırımcılar mı daha fazla getiri elde edebilir sorusu yanıtlanmaya çalışılııştır. Halka arz edilen pay senetlerinin ortalama ilk gün getirisi $\% 6.78$ bulunmakla birlikte bu oranın \%90'ının açılıştaki işlemlerden kaynaklandığı sonucuna ulaşılmıştır. Çalışma sonucunda, düşük fiyatlamadan ilk gün alım yapan yatırımcıların değil, ihraç zamanı alım yapan yatırımcıların daha kazançlı olduğu tespit edilmiştir. Ritter ve Welch (2002),1980-2001 döneminde ABD'de 6,249 ilk halka arzı inceledikleri çalışmada ilk gün getiriyi \%18.8, üçüncü y1l sonundaki getiriyi ise \%22.6 olarak tespit etmiş fakat piyasaya göre düzeltilmiş getirinin ise - $\% 23.4$ olduğunu ortaya koymuştur. ABD'de yapılan diğer çalışmaların bir bölümü de Tablo 1'de özetlenmiştir. Buna göre Chemmanur vd., (2010) tarafından yapılan çalışmada ortalama ilk gün getiri \%54.9 olarak tespit edilirken, Michaely ve Shaw (1994) ilk gün getiriyi $\% 7.27$ olarak tespit etmiştir.

Tablo 1: Düşük fiyatlama ile ilgili yapılmış uluslararası çalışmalar

\begin{tabular}{|l|l|l|r|r|}
\hline Çalışmayı Yapan Kişi(ler) & Ülke & Dönem & N & \multicolumn{1}{|l|}{$\begin{array}{l}\text { İk Gün } \\
\text { AR (\%) }\end{array}$} \\
\hline Aggarwal ve Rivoli (1990) & ABD & $1977-1984$ & 1,598 & 10.67 \\
\hline Ritter (1991) & ABD & $1975-1984$ & 1,526 & 14.30 \\
\hline \multirow{3}{*}{ Aggarwal vd., (1993) } & Brezilya & $1980-1990$ & 62 & 78.50 \\
\cline { 2 - 5 } & Şili & $1982-1990$ & 36 & 16.30 \\
\cline { 2 - 5 } & Meksika & $1987-1990$ & 44 & 2.80 \\
\hline Barry ve Jennings (1993) & ABD & $1988-1990$ & 229 & 6.78 \\
\hline Michaely ve Shaw (1994) & ABD & $1984-1988$ & 947 & 7.27 \\
\hline Ljungquist (1997) & Almanya & $1970-1993$ & 189 & 9.20 \\
\hline Aggarwal (2000) & ABD & 1997 & 114 & 15.82 \\
\hline Giudici ve Paleari (2001) & İtalya & $1985-1999$ & 150 & 24.78 \\
\hline Ljungqvist vd., (2000) & Dünya & $1992-1999$ & 2,143 & 20.20 \\
\hline Chahine (2002) & Fransa & $1996-2000$ & 305 & 17.10 \\
\hline Ritter ve Welch (2002) & ABD & $1980-2001$ & 6,249 & 18.80 \\
\hline Pham vd., (2003) & Avustralya & $1996-1999$ & 113 & 23.41 \\
\hline Chemmanur vd., (2010) & ABD & $1999-2003$ & 934 & 54.90 \\
\hline Kooli ve Suret (2004) & Kanada & $1991-1998$ & 445 & 20.57 \\
\hline Chiang vd., (2011) & Tayvan & $1995-2000$ & 84 & 7.25 \\
\hline Zarafat (2013) & Malezya & $2004-2007$ & 116 & 8.60 \\
\hline Boulton vd., (2013) & Dünya & $1982-2005$ & 5,307 & 13.30 \\
\hline Zhou (2014) & Çin & $1992-2011$ & 2,225 & 98.05 \\
\hline
\end{tabular}


Tablo 1 Devamı: Düşük fiyatlama ile ilgili yapılmış uluslararası çalışmalar

\begin{tabular}{|l|l|l|r|r|}
\hline Miloud (2014) & Fransa & $1995-2008$ & 798 & 15.66 \\
\hline Dell'Acqua vd., (2015) & İtalya & $2001-2012$ & 129 & 6.52 \\
\hline
\end{tabular}

Kaynak: Yazarlar tarafından oluşturulmuştur.

ABD dışındaki diğer ülkelerde de yapılan çalışmalarda ilk gün anormal getirinin varlığ 1 tespit edilmiştir. Örneğin Pham vd., (2003) tarafından 1996-1999 yılları arasında Avustralya'da 113 şirketin incelendiği çalışmada düşük fiyatlama seviyesinin ortalama ilk gün \%23.41, ikinci gün \%1.66, üçüncü gün -\%0.26 olduğu tespit edilmiştir. Kooli ve Suret (2004) Kanada'da 445 pay senedinin kısa dönem fiyat performansını incelemiş; ilk gün getirinin $\% 20.57$ ve piyasaya göre düzeltilmiş ilk gün getirinin ise \%22.57 olduğu sonucuna ulaşmıştır. Benzer şekilde Giudici ve Paleari (2001) İtalya'da ilk halka arzı gerçekleşen 150 şirketin fiyat performansını incelediği çalışmada ilk gün getiriyi \%24.78 olarak tespit etmiş ve kısa dönemde elde edilen getirinin uzun dönemde kaybolduğu sonucuna ulaşmıştır. İtalya'da yapılan bir diğer çalışmada Dell' Acqua vd., (2015) tarafından 129 şirket incelenmiş ve ilk gün ortalama getiri $\% 6.52$, piyasaya göre düzeltilmiş getiri ise $\% 6.75$ bulunmuştur. Chahine (2002) Fransa'da 305 şirket üzerine yapmış olduğu çalışmada ilk gün düşük fiyatlama seviyesini \%17.1 olarak tespit ederken yine Fransa'da Miloud (2014) tarafından yapılan ve 798 ilk halka arzın incelendiği çalışmada ortalama ilk gün getirinin $\% 15.66$ ve yirmi birinci gün getirinin - $\% 0.67$ olduğu tespit edilmiştir. Ljungquist (1997) tarafından Almanya'da 189 şirket üzerine yapılan çalışmada ise ilk gün getirinin \%9.2 olduğu sonucuna ulaşılmıştır.

Chiang vd., (2011) 1995-2000 yılları arasında Tayvan borsasında ilk halka arzı gerçekleşen 84 şirketin ortalama ilk gün getirisinin \%7.25 olduğu ve yıllar itibari ile anormal getirilerin oldukça farklılaştığı sonucuna ulaşmıştır. Zhou (2014) tarafından yapılmış olan çalışmada ise Çin'de ilk halka arzı gerçekleşen 2,225 şirketin fiyat performansı incelenmiştir. İlk gün ortalama \%98.05 oranında anormal getiri elde edildiği ayrıca ilk ayın sonunda ortalama getirinin \%90.42 olduğu tespit edilmiştir. Malezya'da ise Zarafat (2013) tarafından yapılan çalışmada 116 şirket incelenmiş ve ilk gün getiri \%8.60 olarak bulunmuştur.

İlk halka arzda düşük fiyatlama seviyesini inceleyen çalışmaların bir bölümünde ise ülkeler arası karşılaştırmaların yapıldığı görülmektedir. Örneğin; Aggarwal vd., (1993) Brezilya, Şili ve Meksika'da ilk halka arzı gerçekleşen pay senetlerinin fiyat performanslarını incelemiştir. Çalışmada Brezilya'da ilk işlem günü ortalama getiri \%78.5 olarak bulunmuş, Meksika'da ilk işlem günü ortalama getiri \%2.8 ve Şili'de ise \%16.3 olarak tespit edilmiştir. Ljungqvist vd., (2000) ise yapmış oldukları çalışmada 1992-1999 yılları arasında Dünya genelinde yapıllmış olan 2,143 halka arzı incelemişlerdir. Bu şirketlerin 1,411'i Avrupa ülkelerinde, 491'i Asya ülkelerinde, 110'u Kuzey ve Güney Amerika ülkelerinde ve 101'i Afrika ve Ortadoğu ülkelerinde halka arz olmuştur. Tüm örneklem için ortalama ilk gün getirisinin \%20.2, Avrupa ülkeleri için \%19.2, Asya ülkeleri için \%27.5, Kuzey ve Güney Amerika ülkeleri için \%5.4, Afrika ve Ortadoğu ülkeleri için \%14.5 olduğu 
İlk Halka Arzda Düşük Fiyatlama Seviyesi Zamanla Değişiyor Mu? Borsa İstanbul Üzerine Bir Araştırma

tespit edilmiştir. Son olarak Boulton vd., (2013) tarafından 1982 ile 2005 arasındaki 5,307 ilk halka arz incelenmiştir. Riske odaklanmış ve getiriye odaklanmış yatırımcılar açısından yapılan değerlendirmede riske odaklananların $\% 13.3$ ve getiriye odaklananların \%20.3 ilk gün getiri elde ettikleri tespit edilmiştir.

Türkiye'de ise 90'l1 yılların ortalarından itibaren ilk halka arzlarda düşük fiyatlamanın tespitine yönelik çalışmaların yapılmaya başladığı görülmektedir. Yapılan bazı çalışmalarla ilgili özet bilgiler Tablo 2'de raporlanmıştır. Bu konunun incelendiği ilk çalışmalardan biri Kocaman (1995) tarafından yapılmıştır. 35 halka arzın incelendiği çalışmada Türkiye'deki piyasanın geçmişinin yeni olduğu vurgulanmış ve elde edilen sonuçların kesin çıkarsamalar yapmak için yeterli olmadığ 1 ifade edilmiştir. Çalışmada genel olarak şirketlerin ilk hafta getirilerinin yüksek olduğu sonucuna ulaşılmıştır. Ancak ortalama ilk gün ve ilk hafta getiriler, anormal getiriler ve bu getirilerin istatistiki anlamlılığ yapılmamıştır.

Kıymaz (1996) 1990-1995 yılları arasında yedi ayrı sektörde ilk halka arz olan 88 şirketin pay senetlerini incelemiştir. Halka arz fiyatı ve ilk işlem günü kapanış fiyatı dikkate alınarak hesaplanan ilk gün getiri ve ilk işlem günü piyasa getirisine göre düzeltilmiş getirinin hesaplandığ 1 çalışmada ilk gün ortalama getiri $\% 12.3$, ortalama anormal getiri \%12.2 olarak tespit edilmiş ve istatistiksel olarak anlamlı bir getiri ortaya çıktığı sonucuna ulaşılmıştır. Çalışmada ilk günden sonraki günler için hesaplanan kümülatif anormal getiriler de ilk üç hafta boyunca pozitif ve anlamlı bulunmuştur. Ancak uzun dönemde anormal getirinin tersine döndüğü tespit edilmiştir. Kıymaz (2000) ise 1990 ile 1996 yılları arasında halka arz edilmiş 163 şirketin fiyat performansını incelemiştir. Daha geniş bir veri setinin kullanıldığ 1 çalışmada ilk gün getirinin piyasa getirisinin oldukça üzerinde olduğu ve anormal getirinin ortalama $\% 13.1$ olduğu, ikinci gün getirinin ise $\% 4.2$ olduğu tespit edilmiştir. Sektörler açısından yapılan analizde ise sanayi sektörü için \%11.7, finans sektörü için \%15.0 ve diğer sektörler için \%17.6 ortalama anormal getiri oluştuğu belirtilmiştir.

Tablo 2: Düşük fiyatlama ile ilgili Türkiye'de yapılmış çalışmalar

\begin{tabular}{|l|r|r|l|r|r|}
\hline \multicolumn{1}{c|}{$\begin{array}{c}\text { Çalışmayı Yapan } \\
\text { Kişi(ler) }\end{array}$} & \multirow{2}{*}{ Dönem } & \multirow{2}{*}{ N } & \multirow{2}{*}{ Yöntem } & \multicolumn{2}{c|}{ Illk gün } \\
\cline { 5 - 7 } & & & & OG & AR \\
\hline Kiymaz (1996) & $1990-1995$ & 88 & AR & $12.3^{* * *}$ & $12.2^{* * *}$ \\
\hline Kıymaz (2000) & $1990-1996$ & 163 & AR & & $13.1^{* * *}$ \\
\hline Durukan (2002) & $1990-1997$ & 173 & OG & $14.6^{* * *}$ & \\
\hline Aktaş vd., (2003) & $1992-2000$ & 190 & AR & & $9.17^{* * *}$ \\
\hline Teker ve Ekit (2003) & 2000 & 34 & AR & & $0.07^{* * *}$ \\
\hline Yalçıner (2006) & $1997-2004$ & 93 & AR & & $7.2^{* * *}$ \\
\hline Bildik ve Yılmaz (2008) & $1990-2000$ & 234 & ETG & & $5.94^{* *}$ \\
\hline Dağlı ve Kurtaran (2008) & $1993-2005$ & 120 & OG & 13.88 & \\
\hline Kurtaran (2008) & $1990-2006$ & 222 & OG & 15.03 & \\
\hline Ünlü ve Ersoy (2008) & $1995-2008$ & 112 & AR & & 6.52 \\
\hline
\end{tabular}


Tablo 2 Devamı: Düşük fiyatlama ile ilgili Türkiye'de yapılmış çalışmalar

\begin{tabular}{|l|r|r|l|r|r|}
\hline Kurkulak (2010) & $1995-2004$ & 150 & ETG* & $8.26^{* * *}$ & \\
\hline Tükel (2010) & $2000-2007$ & 42 & AR & & $10,9 * * *$ \\
\hline Sağlam ve Çelik (2011) & $1993-2006$ & 40 & AR & & 11.30 \\
\hline Otlu ve Ölmez (2011) & $2006-2011$ & 53 & AR & & $6.99 * * *$ \\
\hline Kaya (2012) & $2010-2011$ & 32 & ARP & & 2,4 \\
\hline Elmas (2013) & $1995-2010$ & 227 & AR & & $8.80 * * *$ \\
\hline Oran vd., (2013) & $2008-2013$ & 61 & OG & 8.30 & \\
\hline Kurtaran (2013) & $1994-2009$ & 205 & OG & $8.32 * * *$ & \\
\hline
\end{tabular}

AR: Piyasa getirisine göre düzeltilmiş ortalama anormal getiri, $\mathrm{AR}_{\mathrm{P}}$ : Piyasa modeli kullanılarak düzeltilmiş ortalama anormal getiri, ETG: Elde tutma getirisi, OG: İlk gün kapanış göre ortalama getiri $\mathrm{OG}_{\mathrm{I}}$ : İlk gün açılış fiyatına göre ortalama getiri

Kaynak: Yazarlar tarafından oluşturulmuştur.

Aktaş vd., (2003) 1992-2000 y1lları arasında 190 şirketin kısa dönem performansında etkili olan faktörleri inceledikleri çalışmada ilk gün anormal getiriyi \%9.17 olarak tespit etmişlerdir. Önceki çalışmalardan daha düşük ilk gün anormal getirinin tespit edildiği çalışmada ayrıca yedinci ve on beşinci gündeki kümülatif anormal getiriler sırasıyla \%13.94 ve \%12.46 olarak tespit edilmiştir. Yalçıner (2006) 1997-2004 yılları arasında ilk halka arz edilen 93 şirketin kısa dönem fiyat performans1 ve ayrıca pay senedinin ihraç fiyatı büyüklüğü ile ihraç yöntemlerine göre fiyat performansı arasındaki ilişkiyi araştırmışıı. Çalışmada ilk işlem günü anormal getirinin \%7.2 olduğu ve istatistiksel olarak anlamlı olduğu tespit edilmiş, üçüncü günden sonra anormal getirinin istatistiksel olarak anlamlı olmadığ1 sonucuna ulaşılmıştır. Küçükkocaoğlu ve Alagöz (2009) 1993 ile 2005 yılları arasında 178 ilk halka arzı inceledikleri çalışmada halka arzda satış yöntemlerine göre düşük fiyatlamanın değişip değişmediğini incelemişlerdir. Sabit fiyatla talep toplama yönteminin ilk gün getirisi \% 7.66, fiyat aralığıla talep toplama yönteminin ilk gün getirisi \%10.62 olarak hesaplanmıştır. Tükel (2010) 2000-2007 yılları arasında ilk halka arzı gerçekleşen 42 şirketin kısa ve uzun dönem fiyat performansını incelemiştir. İlk gün ortalama anormal getirinin \%10.94 olduğu ve ilk ay ortalama getirinin ise \%27.95 olduğu tespit edilmiş̧ir. Çalışmada ayrıca otuz altıncı ayın sonunda kadar analiz genişletilmiş ve kısa dönemdeki anormal getirinin uzun vadede de devam ettiği sonucuna ulaşılmıştır. Otlu ve Ölmez (2011) 2006 ile 2011 yılları arasında 53 pay senedinin 21 günlük ortalama anormal getirilerini ve kümülatif anormal getirilerini incelemişlerdir. Çalışmada ilk halka arz edilen şirketlerin beta değerlerinin hesaplanamayacağı ve betanın 1 kabul edildiği vurgulanarak piyasaya göre düzeltilmiş anormal getiri hesaplanmıştır. İlk gün ortalama anormal getiri \%6.99 ve ortalama 21 günlük kümülatif anormal getiri \%8.6 olarak bulunmuştur. Çalışmada ilk iki günde düzeltilmiş anormal getirinin varlığ tespit edilmiş kümülatif anormal getirinin ise tüm günlerde anlamlı olduğu raporlanmıştır. Elmas (2013) 1995-2010 yılları arasında 227 şirketi araştırma kapsamına almıştır. İlk gün ortalama anormal getiri \%8.8 bulunmuştur. Ayrıca alt sektörler itibari ile ilk gün getirinin finans sektörü için \%10, bilişim sektörü için 
İlk Halka Arzda Düşük Fiyatlama Seviyesi Zamanla Değişiyor Mu? Borsa İstanbul Üzerine Bir Araştırma

\%6.7, sanayi sektörü için \%8.8 ve diğer sektörler için \%5.9 olarak hesaplanmıştır. İlk gün hariç kümülatif anormal getirilerin de hesaplandığı çalışmada ilk ay için kümülatif anormal getiri -\%0.7 olarak bulunmuştur. Kurtaran (2013) 1994-2009 yılları arasında ilk halka arzı gerçekleşen 205 şirketin kısa ve uzun dönem fiyat performanslarını araştırmıştır. Uzun dönem fiyat performansını satın alt ve tut yöntemi ile kümülatif anormal getiri yöntemine göre ayrı ayrı incelemiştir. İlk gün getirinin \%8.32 olduğu sonucuna ulaşılmıştır. Uzun dönemde kümülatif getiriler birinci ay $\% 7.48$, üçüncü ay $\% 5.37$, satın al ve tut yöntemine göre; birinci ay $\% 7.48$, üçüncü ay $\% 6.62$ bulunmuștur.

İlk halka arzda düşük fiyatlama bazı çalışmalarda elde tutma getirisi hesaplanarak da ortaya konulmuştur. Örneğin; Bildik ve Yılmaz (2008) 1990 ve 2000 yılları arasında 224 şirket için ilk halka arzların kısa ve uzun dönem fiyat performanslarını incelemişlerdir. Elde tutma getirisi üzerinden hesaplanan ilk gün düşük fiyatlama seviyesinin $\% 5.94$, ikinci günde ise $\% 7.83$ olduğu ve istatistiksel açıdan anlamlı olduğu ayrıca birinci, ikinci ve üçüncü yılsonunda elde edilen getirilerin sırasıyla \% $\% .3,-\% 13.03$ ve - $\% 84.5$ olduğu tespit edilmiştir. Benzer şekilde Kırkulak (2010)'da elde tutma getirisi hesaplayarak, 1995-2004 yılları arasında ilk halka arzı gerçekleşen 150 şirketin kısa ve uzun dönem fiyat performansını incelemiştir. Ortalama ilk gün getirinin $\% 8.26$, ilk gün hariç bir aylık elde tutma getirisi ise piyasaya göre düzeltilmiş $\% 8.48$ olarak tespit edilmiştir. Y1llar itibari ile ilk gün getirisi farklılaşsa da bu farkın yıllık bazda istatistiki olarak anlamlı olmadığ 1 sonucuna ulaşmıştır.

Teker ve Ekit (2003) ise anormal getiri hesaplama yöntemi olarak piyasa modelini kullanmış, 2000 yılında ilk halka arzı gerçekleşen 34 pay senedinin otuz günlük fiyat performansını incelemişlerdir. Piyasa modeline göre düzeltilmiş ilk gün getiri \%7; otuz günlük kümülatif getiri -\% $\% .21$ bulunmuştur. Benzer şekilde piyasa modeline göre anormal getirinin tahmin edildiği diğer bir çalışma ise Kaya (2012) tarafından yapılmıştır. 32 şirketten oluşan, 2010-2011 dönemini kapsayan küȩük bir örneklemde kısa dönem fiyat performansı incelenmiştir. Çalışmada kısa dönemi ilk günden itibaren ilk dört gün, ilk hafta, bir aylık, üç aylık ve altı aylık dönemlere ayrılmıştır. Çalışmada beta hesaplanmasında benzer ölçekte ve aynı sektörde şirketlerin beta değerleri kullanılmıştır. Anormal getiriler ilk gün için \%2.4, ilk hafta için $\% 7.8$, ilk ay için $\% 7.5$ olarak bulmuştur.

Bazı çalışmalarda ise hesaplanan anormal getirinin anlamlılı̆̆ 1 ile ilgili istatistiksel bir analiz yapılmamıştır. Örneğin; Ünlü ve Ersoy (2008) 1995 ve 2008 döneminde 112 pay senedi için yapılan araştırmada kısa dönem fiyat performansını incelemiştir. Ortalama ilk gün getiri \%6.52, ortalama kümülatif getiri ise (21 günlük) \%5.35 olarak bulunmuştur. Benzer şekilde Sağlam ve Çelik (2011) tarafından yapılan çalışmada da, 1993-2006 yılları arasında, tek bir aracı kurum tarafından ilk halka arzı gerçekleşen 40 pay senedinin fiyat performansını incelemişlerdir. Çalışmada ilk gün anormal getiri \%11.30 olarak hesaplanmıştır.

Çalışmaların bir bölümünde ise ilk gün düşük fiyatlama ile ilgili olarak piyasaya göre düzeltilmemiş ilk gün ortalama getirilerin hesaplandığı görülmektedir. 
Örneğin; Durukan (2002) tarafindan yapılmış olan çalışmada 1990-1997 y1lları arasında ilk halka arzı gerçekleşen 173 şirketin kısa ve uzun dönem fiyat performansı incelenmiştir. Açılışa göre getiri ve gün içi getirinin hesaplandığı çalışmada halka arz fiyatından alım yapan yatırımcının ilk gün açııış fiyatına göre \%16.16 istatistiksel olarak anlamlı getiri elde edeceği tespit edilmiş, kapanış fiyatına göre ise \%14.6 getiri oluştuğu belirlenmiştir. Ayrıca on iki, yirmi dört ve otuz altı aylık halka arz performanslarının incelendiği çalışmada on iki aylık getirinin \%5.82 olduğu tespit edilmiştir. İlk gün ortalama getirinin hesaplandığı çalışmalara örnek olarak Dağlı ve Kurtaran (2008), Kurtaran (2008) ve Oran vd., (2013) tarafından yapılan çalışmalar gösterilebilir. Ancak bu çalı̧̧malarda hesaplanan ortalama getirinin istatistiksel olarak anlamlılığı ile ilgili bir değerlendirme yapılmamıştır. Dağlı ve Kurtaran (2008) mali sektör hariç diğer sektörlerde yer alan 120 ilk halka arzı araştırmışlardır. İlk gün ortalama getirinin halka arz fiyatı ile ilk işlem fiyatına göre belirlendiği çalışmada ilk gün getiri \%13.88 bulunmuştur. Benzer şekilde Kurtaran (2008) ise 1990-2006 yılları arasındaki ilk halka arz edilen 222 şirketi kapsayan örneklem için ilk gün açılış fiyatına göre ortalama getiriyi \%15.03 olarak tespit etmiştir. Oran vd., (2013) tarafindan yapılan çalışmada da, aracı kurumlar tarafından yapılan gerçeğe uygun değer tahminlerinin istatistiksel olarak gerçek piyasa değerinden farklı olduğu tespit edilmiş ve ilk gün düşük fiyatlama düzeyi $\% 8.30$, onuncu günde $\% 14$ ve otuzuncu günde $\% 12$ olarak hesaplanmıştır.

\section{Araştırmanın Veri Seti ve Metodoloji}

Çalışmada 1993-2015 yıllarını kapsayan 22 yıllık dönemde ilk halka arzı gerçekleştirilen şirketler örneklem olarak kullanılmıştır. Bu dönemde Borsa İstanbul'da 320 şirketin halka arzı gerçekleşmiştir. Bu şirketler için yapılan analizlerden sonra piyasa modeline göre getiri hesaplaması yapabilmek için eksik verisi bulunan şirketler örneklemden çıkarılarak 265 şirketten oluşan bir alt örneklem için 3 farklı anormal getiri hesaplaması tekrar yapılmıştır. Bu örneklem de kendi içerisinde iki gruba ayrılmış; mali sektörde faaliyet gösteren 76 şirket ve reel sektör de faaliyet gösteren 179 şirket için ilk 20 günlük anormal getiri hesaplanarak istatistiksel açıdan bu iki grubun farklı düşük fiyatlama sergileyip sergilemediği test edilmiştir.

Çalışmamızda ilk halka arzı gerçekleştirilen şirketlerin ilk yirmi işlem gününü kapsayan anormal getiri performansı incelenmiştir. İlk halka arzda ilk gün düşük fiyatlama düzeyinin tespiti için pay senetlerinin halka arz fiyatları ve ilk işlem günündeki kapanış fiyatlarından yararlanılarak ilk gün getirisi hesaplanmıştır.

$$
R_{i, 1}=\left(P_{\mathrm{i} L K}-P_{\mathrm{i} H}\right) / P_{\mathrm{i} H}
$$

$P_{\text {ILK: }}$ Pay senedinin halka arz sonrası ilk işlem gün kapanış fiyatı

$\mathrm{P}_{\mathrm{iн}}$ : Pay senedinin halka arz fiyatı

Elde edilen bu getiri pay senedinin işlem gördüğü gün piyasanın getirisine göre düzeltilerek $\left(\mathrm{AR}_{\mathrm{T}}\right)$, pay senedinin ihraç tarihi ve ilk işlem gördüğü tarih arasında piyasanın getirisine göre düzeltilerek $\left(A_{D}\right)$ ve piyasa modeli kullanılarak tahmin 
İlk Halka Arzda Düşük Fiyatlama Seviyesi Zamanla Değişiyor Mu? Borsa İstanbul Üzerine Bir Araştırma

edilen getiriye göre düzeltilerek $\left(\mathrm{AR}_{\mathrm{P}}\right)$ üç farklı anormal getiri hesaplanmıştır. Buna göre:

$$
A R_{T}=R_{i, 1}-R_{m, 1}
$$

$\mathrm{R}_{\mathrm{i}, 1}$ : Pay senedinin halka arz fiyatı ile ilk işlem gördüğü gün kapanış fiyatı dikkate alınarak hesaplanan getiriyi

$\mathrm{R}_{\mathrm{m}, 1}$ : Pay senedinin borsada ilk işlem gördüğü gündeki BIST 100 endeksinin günlük getirisini ifade etmektedir.

$\mathrm{AR}_{\mathrm{D}}$ ise yukarıda belirtildiği gibi hesaplanan pay senedinin ilk işlem günü getirisinin $\left(\mathrm{R}_{\mathrm{i}, 1}\right)$ aynı dönemdeki BIST 100 endeksinin getirisi ile arasındaki farktan yararlanılarak hesaplanan anormal getiridir.

$$
A R_{D}=R_{i, 1}-R_{m, D}
$$

$\mathrm{R}_{\mathrm{m}, \mathrm{D}}$ : pay senedinin halka arz tarihi ile ilk işlem gördüğü tarih arasında geçen sürede BIST 100 endeksin getirisi

İlk günden sonraki günler için pay senedi ve endeksin bir önceki güne göre getirisi hesaplanmış ve aralarındaki fark anormal getiri olarak tanımlanmıştır. $\mathrm{Bu}$ çerçevede ilk gün kapanıştan sonraki günler için $\mathrm{AR}_{T}$ ve $\mathrm{AR}_{\mathrm{D}}$ değerleri aynıdır.

Çalışmamızda anormal getirinin hesaplanmasında üçüncü bir yöntem olarak piyasa modeli kullanılmıştır. Buna göre hisse senedinin beklenen getirisi tespit edilmiş $\left(\hat{R}_{i, t}\right)$ ve beklenen getiri ile gerçekleşen getiri arasındaki fark anormal getiri olarak tanımlanmıştır. Piyasa modelini kullanan çalışmalarda yeni ihraç edilen pay senedinin geçmiş fiyat verileri olmadığı için betasının 1'e eşit olduğu kabul edilmekte veya benzer sektörde ve büyüklükteki şirketin betası kullanılmaktąфır. Çalışmamızda bu yaklaşımlardan farklı olarak anormal getiri hesaplamasında halka arzdan sonrası ilk 20 işlem günü ve 20 işlem gününden sonraki 200 işlem günü olarak iki ayrı zaman penceresi oluşturulmuştur. İkinci periyod olan 200 işlem günlük dönemde piyasa modeline göre alfa ve beta katsayıları hesaplanmış ve birinci periyod olan 20 işlem günlük dönem için pay senetlerinin beklenen getiriler hesaplanmıştır. İlk 20 gün için beklenen getiriler 200 günlük pencere kullanılarak hesaplanan $\hat{\alpha}_{i}$ ve $\hat{\beta}_{i}$ yardımı ile aşağıdaki şekilde hesaplanmıştır:

$$
\hat{R}_{i, t}=\hat{\alpha}_{i}+\hat{\beta}_{i} \times R_{m, t}
$$

$\hat{R}_{i, t}$ : i pay senedinin $\mathrm{t}$ günündeki beklenen getirisi

$R_{m, t}$ : BIST 100 endeksinin $\mathrm{t}$ günündeki gerçekleşen getirisini ifade etmektedir.

Elde edilen tahmini (beklenen getiriler) ile gerçekleşen getiriler arasındaki fark alınarak piyasa modeline göre düzeltilmiş anormal getiriler aşağıdaki şekilde tespit edilmiştir:

$$
A R_{P}=R_{i, t}-\hat{R}_{i, t}
$$

Anormal getiriler kullanılarak kümülatif anormal getiriler aşağıdaki formül yardımı ile hesaplanmıştır. 


$$
C A R_{i, t}=\sum_{t=1}^{n} A R_{i, t}
$$

$C A R_{i, t}$ : i pay senedinin $\mathrm{t}$ günündeki kümülatif anormal getirisini

$A R_{i, t}$ : Pay senetlerinin günlük anormal getirilerini ifade etmektedir.

\section{Bulgular}

320 şirketten oluşan veri seti için hesaplanan anormal getiriler $\left(A_{T}\right.$ ve $\left.A R_{D}\right)$ Tablo 3'de raporlanmıştır. Ayrıca piyasa modeline göre anormal getiri hesaplanması yapılabilen 265 şirket için riske göre düzeltilmiş ortalama anormal getiri $\left(A_{P}\right)$ hesaplanmış ve bu örneklem için $\mathrm{AR}_{\mathrm{T}}$ ve $\mathrm{AR}_{\mathrm{D}}$ değerleri de karşılaştırma imkânı sağlamak amacı ile tekrar hesaplanarak tabloda raporlanmıștır. Tüm örneklem için ilk işlem günü ortalama anormal getiri $\left(\mathrm{AR}_{\mathrm{D}}\right) \% 6.6$ olarak tespit edilmiştir. İlk işlem günü piyasa getirisinin çıkarılması ile elde edilen ilk gün düzeltilmiş getiri ise $\left(\mathrm{AR}_{\mathrm{T}}\right)$ \%7.3 olarak bulunmuştur. 265 şirketten oluşan örneklem için piyasa modeline göre hesaplanan anormal getiri $\left(\mathrm{AR}_{\mathrm{P}}\right)$ ise \%7.2'dir. Aynı örneklem için hesaplanan ortalama $A R_{T}$ ve $A R_{D}$ değerleri ise sırasıyla \%7.2 ve \%6.4 olarak tespit edilmiştir.

Tablo 3: Farkl hesaplama yöntemlerine göre ilk gün anormal getiri

\begin{tabular}{|c|c|c|c|c|c|c|c|c|}
\hline & $\mathbf{N}$ & & Min. & Mak. & Med. & Ort. & S.S. & t-ist. \\
\hline \multirow{2}{*}{$\begin{array}{l}\text { Tüm } \\
\text { Örneklem }\end{array}$} & \multirow{2}{*}{320} & $\mathrm{AR}_{\mathrm{T}}$ & -0.315 & 0.545 & 0.063 & 0.073 & 0.120 & $10.94 * * *$ \\
\hline & & $\mathrm{AR}_{\mathrm{D}}$ & -0.631 & 0.685 & 0.047 & 0.066 & 0.136 & $8.67 * * *$ \\
\hline \multirow{3}{*}{$\begin{array}{l}\text { İkinci } \\
\text { Örneklem }\end{array}$} & \multirow{3}{*}{265} & $\mathrm{AR}_{\mathrm{T}}$ & -0.297 & 0.545 & 0.059 & 0.072 & 0.118 & $9.90 * * *$ \\
\hline & & $\mathrm{AR}_{\mathrm{D}}$ & -0.631 & 0.449 & 0.053 & 0.064 & 0.132 & $7.87 * * *$ \\
\hline & & $\mathrm{AR}_{\mathrm{P}}$ & -0.299 & 0.544 & 0.063 & 0.072 & 0.118 & $9.89 * * *$ \\
\hline \multirow{3}{*}{$\begin{array}{l}\text { Reel } \\
\text { Sektör }\end{array}$} & \multirow{3}{*}{179} & $\mathrm{AR}_{\mathrm{T}}$ & -0.191 & 0.545 & 0.056 & 0.071 & 0.119 & $7.97 * * *$ \\
\hline & & $\mathrm{AR}_{\mathrm{D}}$ & -0.631 & 0.442 & 0.053 & 0.063 & 0.126 & $6.66^{* * *}$ \\
\hline & & $\mathrm{AR}_{\mathrm{P}}$ & -0.183 & 0.544 & 0.061 & 0.070 & 0.119 & $7.86^{* * *}$ \\
\hline \multirow{3}{*}{$\begin{array}{l}\text { Mali } \\
\text { Sektör }\end{array}$} & \multirow{3}{*}{86} & $\mathrm{AR}_{\mathrm{T}}$ & -0.297 & 0.297 & 0.083 & 0.074 & 0.117 & $5.86^{* * *}$ \\
\hline & & $\mathrm{AR}_{\mathrm{D}}$ & -0.542 & 0.449 & 0.053 & 0.066 & 0.144 & $4.24 * * *$ \\
\hline & & $\mathrm{AR}_{\mathrm{P}}$ & -0.299 & 0.296 & 0.082 & 0.075 & 0.116 & $6.00 * * *$ \\
\hline
\end{tabular}

$\% 1, \% 5$ ve $\% 10$ düzeyinde istatistiksel anlamlılık, sirasiyla $* * *, * *$ ve $*$ ile gösterilmiştir.

Tüm bu oranlar istatistiksel açıdan \%1 anlamlılık düzeyinde sıfırdan farklı bir getiriye diğer bir ifade ile halka açılan şirketlerde düşük fiyatlamanın güçlü bir şekilde varlığına işaret etmektedir. Hangi hesaplama yöntemi seçilirse seçilsin \%6.4 ile \%7.2 arasında bir ortalama ilk gün anormal getiri ortaya çıkmaktadır. Reel sektör şirketleri ve mali sektör şirketleri açısından da bu durum değişmemektedir. $\mathrm{AR}_{\mathrm{D}}$ reel sektör için \%6.3 iken mali sektörde \%6.6'dır. AR değerleri de reel sektör için \%7 iken mali sektörde $\% 7.5$ 'dir. Bu sonuçlar ilk gün düşük fiyatlama olgusunun sektörel açıdan farklılaşmadığını ve her iki grup için de geçerli olduğunu göstermektedir. 
Ilk Halka Arzda Düşük Fiyatlama Seviyesi Zamanla Değişiyor Mu? Borsa İstanbul Üzerine Bir Araştırma

Hesaplanan $\mathrm{AR}_{\mathrm{T}}$ ve $\mathrm{AR}_{\mathrm{D}}$ değerleri ilk günden sonra birbirine eşit olacağ için bundan sonraki analizlerde $\mathrm{AR}_{\mathrm{T}}$ dikkate alınmamış ve karşılaştırmalar 265 şirketten oluşan örneklem için $A R_{D}$ ve $A R_{P}$ değerleri üzerinden yapılmıştır. İlk gün ortaya çıkan anormal getirinin daha sonraki günlerde de devam edip etmediğini araştırmak amacı ile 20 günlük anormal getiriler hesaplanarak istatistiksel açıdan anlamlı olup olmadığg test edilmiştir. Anormal getiriler Tablo 4'de ve Şekil 1'de, kümülatif anormal getiriler ise Tablo 5'de raporlanmıştır. Tablo 4 incelendiğinde her iki yönteme göre de hesaplanan anormal getirilerin ilk üç gün için pozitif ve anlamlı olduğu görülmektedir. Buna göre örneğin $\mathrm{AR}_{P}$ ilk gün getiri \%7.16 iken ikinci günde $\% 2.13$ üçüncü günde ise \%0.91 olarak gerçekleşmiş ve her üç gün için de bu ortalamalar istatistiksel açıdan sıfirdan farklı olarak bulunmuştur.

Tablo 4: Illk yirmi günlük anormal getiriler

\begin{tabular}{|c|c|c|c|c|c|c|}
\hline & \multicolumn{3}{|c|}{$\mathbf{A R} \mathbf{R}_{\mathbf{D}}$} & \multicolumn{3}{|c|}{$\mathbf{A R}_{\mathbf{P}}$} \\
\hline Günler & Ort. & S.S. & t-ist. & Ort. & S.S. & t-ist. \\
\hline 1 & 0.0638 & 0.132 & $7.87 * * *$ & 0.0716 & 0.113 & $9.89 * * *$ \\
\hline 2 & 0.0221 & 0.084 & $4.27 * * *$ & 0.0213 & 0.083 & $4.17 * * *$ \\
\hline 3 & 0.0087 & 0.075 & $1.89^{*}$ & 0.0091 & 0.074 & $2.01 * *$ \\
\hline 4 & 0.0058 & 0.073 & 1.29 & 0.0068 & 0.072 & 1.53 \\
\hline 5 & 0.0004 & 0.058 & 0.09 & -0.0012 & 0.058 & -0.33 \\
\hline 6 & 0.0018 & 0.053 & 0.56 & 0.0013 & 0.055 & 0.38 \\
\hline 7 & -0.0036 & 0.056 & -1.04 & -0.0044 & 0.056 & -1.30 \\
\hline 8 & -0.0061 & 0.048 & $-2.09 * *$ & -0.0060 & 0.047 & $-2.11 * *$ \\
\hline 9 & 0.0004 & 0.048 & 0.13 & -0.0002 & 0.048 & -0.08 \\
\hline 10 & -0.0031 & 0.045 & -1.13 & -0.0035 & 0.045 & -1.24 \\
\hline 11 & -0.0048 & 0.079 & -1.01 & -0.0038 & 0.080 & -0.78 \\
\hline 12 & -0.0009 & 0.041 & -0.35 & -0.0001 & 0.040 & -0.05 \\
\hline 13 & 0.0015 & 0.045 & 0.55 & 0.0005 & 0.045 & 0.1980 \\
\hline 14 & -0.0074 & 0.037 & $-3.28 * * *$ & -0.0076 & 0.037 & $-3.32 * * *$ \\
\hline 15 & -0.0009 & 0.037 & -0.38 & -0.0021 & 0.038 & -0.91 \\
\hline 16 & -0.0009 & 0.042 & -0.34 & -0.0008 & 0.042 & -0.32 \\
\hline 17 & -0.0040 & 0.042 & -1.56 & -0.0045 & 0.043 & $-1.68 *$ \\
\hline 18 & 0.0034 & 0.067 & 0.83 & 0.0027 & 0.067 & 0.65 \\
\hline 19 & 0.0018 & 0.040 & 0.71 & 0.0015 & 0.039 & 0.60 \\
\hline 20 & -0.0003 & 0.042 & -0.11 & 0.0001 & 0.040 & 0.02 \\
\hline
\end{tabular}

İlk gün anormal getirinin sonraki günlerde düşme eğiliminde olduğu gözlenmektedir. Beşinci gün ve sonrasında beşinci günden yirminci güne kadar olan on altı günlük sürenin on bir gününde negatif getiri ortaya çıtığı tespit edilmiştir. $\mathrm{Bu}$ getirilerin bir bölümü de istatistiksel olarak anlamlıdır. Anormal getirilerin ilk yirmi günlük seyrini gösteren Şekil 1'de bu durum net bir şekilde gözlenmektedir. Sonuç olarak, anormal getirideki bu seyir ilk üç günde ortaya çıkan anormal getirinin daha sonra yatırımcılar tarafından realize edildiği şeklinde yorumlanabilir. 


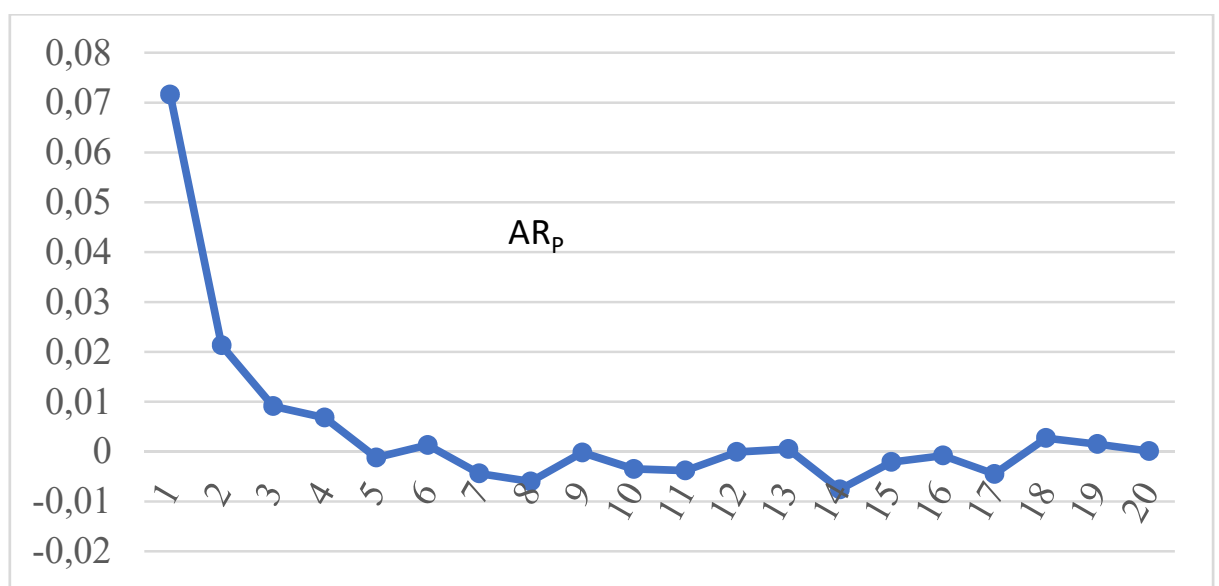

Şekil 1: Ilk halka arzda kısa dönem günlük ortalama anormal getiri

İlk halka arz fiyatı ile borsada işlem görmeye başladıktan sonraki yirmi gün süreyle ortaya çıkan kümülatif anormal getiriler ise Tablo 5'de raporlanmıştır. Tablodan da görüleceği gibi hem piyasaya göre düzeltilmiş getiriler kullanılarak hesaplanan kümülatif anormal getiriler $\left(\mathrm{CAR}_{\mathrm{D}}\right)$ hem de piyasa modeline göre tespit edilen anormal getirilere göre hesaplanmış kümülatif anormal getiriler $\left(C_{A} R_{P}\right)$ yirmi günlük süre boyunca pozitif ve istatistiksel olarak anlamlı bulunmuştur. Örneğin $\mathrm{CAR}_{\mathrm{P}}$ değerleri incelendiğinde ilk işlem günü gerçekleşen ilk işlem günü gerçekleşen getiri \%7.16 iken ikinci gün kapanışa göre hesaplanan $\mathrm{CAR}_{1,2} \% 9.29$ üçüncü gün kapanış fiyatına göre hesaplanan $\mathrm{CAR}_{1,3} \% 10.20$ bulunmuştur. Dördüncü günden sonra kümülatif anormal getirinin düşme eğilimine girdiği ve yirminci günün sonunda \%8.04'e gerilediği görülmektedir. Alt dönemler itibariyle bakıldığında beşinci ve onuncu gün arasında ortaya çıkan kümülatif anormal getirinin $\left(\mathrm{CAR}_{5,10}\right)$-\%1.41 olduğu yine on bir on beşinci günler arasında ortaya çıkan kümülatif anormal getirinin $\left(\mathrm{CAR}_{11,15}\right)-\% 1.31$ olup bu negatif getirinin istatistiksel olarak da anlamlı olduğu tespit edilmiştir. Diğer bir ifadeyle beşinci günden on beşinci güne kadar ortaya çıkan anormal getirilerin toplamı CAR $5,15-\% 2.72$ 'dir ve $\% 5$ anlamlılık düzeyinde sıfirdan farklı negatif getiriye işaret etmektedir. Bu durum pay senedini ilk halka arz fiyatından satın alan yatırımcının ilk üç günde gerek piyasa modeline göre düzeltilmiş gerekse piyasaya göre düzeltilmiş anormal getiri sağlayabileceğini bu dönemden sonra ise pay senedi fiyatlarının ortalama olarak düşmesinden dolayı elde edeceği getirinin azaldığını göstermektedir.

Tablo 5: Kümülatif anormal getiriler

\begin{tabular}{|l|r|c|c|r|r|c|}
\hline & \multicolumn{3}{|c|}{ CAR } & \multicolumn{3}{c|}{ CARP } \\
\hline & Ortalama & \multicolumn{1}{|c|}{ S.S. } & t-ist & Ortalama & \multicolumn{1}{c|}{ S.S. } & t-ist \\
\hline CAR $_{1}$ & 0.0638 & 0.132 & $7.87^{* * *}$ & 0.0716 & 0.118 & $9.89^{* * *}$ \\
\hline CAR $_{1,2}$ & 0.0859 & 0.180 & $7.76^{* * *}$ & 0.0929 & 0.173 & $8.73^{* * *}$ \\
\hline CAR $1,3^{3}$ & 0.0946 & 0.222 & $6.93^{* * *}$ & 0.1020 & 0.220 & $7.56^{* * *}$ \\
\hline
\end{tabular}


Ilk Halka Arzda Düşük Fiyatlama Seviyesi Zamanla Değişiyor Mu? Borsa İstanbul Üzerine Bir Araştırma

Tablo 5 Devamı: Kümülatif anormal getiriler

\begin{tabular}{|l|r|r|r|r|r|r|}
\hline CAR $_{1,4}$ & 0.1005 & 0.253 & $6.46^{* * *}$ & 0.1088 & 0.255 & $6.95 * * *$ \\
\hline CAR $_{1,5}$ & 0.1008 & 0.271 & $6.05^{* * *}$ & 0.1076 & 0.274 & $6.38^{* * *}$ \\
\hline CAR $_{1,6}$ & 0.1026 & 0.285 & $5.86^{* * *}$ & 0.1088 & 0.291 & $6.08^{* * *}$ \\
\hline CAR $_{1,7}$ & 0.0990 & 0.296 & $5.44 * * *$ & 0.1044 & 0.307 & $5.54 * * *$ \\
\hline CAR $_{1,8}$ & 0.0929 & 0.302 & $5.01 * * *$ & 0.0984 & 0.313 & $5.11^{* * *}$ \\
\hline CAR $_{1,9}$ & 0.0933 & 0.313 & $4.85 * * *$ & 0.0981 & 0.327 & $4.89 * * *$ \\
\hline CAR $_{1,10}$ & 0.0902 & 0.319 & $4.60^{* * *}$ & 0.0947 & 0.332 & $4.61^{* * *}$ \\
\hline CAR $_{1,15}$ & 0.0777 & 0.344 & $3.67 * * *$ & 0.0815 & 0.367 & $3.61^{* * *}$ \\
\hline CAR $_{1,20}$ & 0.0777 & 0.373 & $3.39 * * *$ & 0.0804 & 0.406 & $3.22^{* * *}$ \\
\hline CAR $_{5,10}$ & -0.0103 & 0.158 & -1.06 & -0.0141 & 0.165 & -1.39 \\
\hline CAR $_{11,15}$ & -0.0125 & 0.115 & $-1.77 *$ & -0.0131 & 0.125 & $-1.72 *$ \\
\hline CAR $_{5,15}$ & -0.0227 & 0.201 & $-1.84 *$ & -0.0272 & 0.224 & $-1.98^{* *}$ \\
\hline CAR $_{16,20}$ & 0.0000 & 0.124 & -0.01 & -0.0011 & 0.125 & -0.14 \\
\hline
\end{tabular}

$\% 1, \% 5$ ve $\% 10$ düzeyinde istatistiksel anlamlılı, sirasıly $* * *, * *$ ve $*$ ile gösterilmiştir.

22 yılı kapsayan araştırma dönemi içerisinde şüphesiz halka arzın tarafları olan aracı kurumlar, yatırımcılar ve halka arz edilen şirketlerin halka arz ile ilgili bilgi ve deneyimleri artmış, halka arz süreçlerinde gelişmeler yaşanmış, finansal piyasalar ve makroekonomik şartlar değişmiştir. Bu dönem boyunca halka arzda düşük fiyatlama düzeyinin de değişmesi mümkündür. Zaman içerisinde halka arzda anormal getirinin nasıl değiş̧tiği ile ilgili çeşitli ampirik çalışmalar yapılmış ancak bu çalışmalarda yıllar bazında halka arz edilen şirketlerin ortalama anormal getirileri tespit edilerek bir değerlendirme yapılmıştır. Ancak hesaplanan anormal getirinin örneklem sayısına duyarlılı̆̆ yıl bazlı değerlendirmeyi çok da anlamlı hale getirmemektedir. Çünkü örneğin 2000 yılında 36 ilk halka arz gerçekleşmişken 2002 yılında 4, 2014 yılında 9 ilk halka arzın gerçekleştiği tespit edilmiştir. Her yıl için o yıl gerçekleştirilen halka arzları dikkate alarak o yıl için hesaplanan anormal getirilerin karşılaştırılması sağlıklı sonuç vermeyecektir. Bu sakıncadan dolayı çalışmamızda şirketler halka arz tarihlerine göre sıralanmış ve 125 'er şirketten oluşan örneklemler için hareketli ortalama esasına göre anormal getiriler hesaplanmıştır. Buna göre birinci grup Şubat 1993 ile Temmuz 2000 arasında halka arzı gerçekleşen 125 şirketten oluşurken ikinci grup Şubat 1993'den itibaren ilk 15 şirketin çıkarılması ve Temmuz 2000'den sonra halka arzı gerçekleşen ilk 15 şirketin örnekleme alınmasıyla yine 125 şirketlik örneklem üzerinden oluşturulmuştur. $\mathrm{Bu}$ süreç 2015 yılına kadar devam ettirilmiş ve toplam 11 alt örneklem için ortalama ilk gün anormal getiriler hesaplanmıştır. Elde edilen sonuçlar Tablo 6'da görülmektedir.

Tablo 6: Ylllar itibariyle ortalama anormal getiri değişimi

\begin{tabular}{|l|c|r|r|r|l|}
\hline & \multicolumn{1}{|c|}{ Dönem } & \multicolumn{1}{c|}{ N } & \multicolumn{1}{c|}{ Ort. ARP } & \multicolumn{1}{c|}{ S.S. } & \multicolumn{1}{|c|}{ t-ist. } \\
\hline Dönem 1 & $02.1993-07.2000$ & 125 & 0.088 & 0.132 & $7.506^{* * *}$ \\
\hline Dönem 2 & $06.1994-02.2002$ & 125 & 0.082 & 0.127 & $7.220^{* * *}$ \\
\hline
\end{tabular}

Tablo 6: Ylllar itibariyle ortalama anormal getiri değişimi 
Tablo 6 Devamı: Yıllar itibariyle ortalama anormal getiri değişimi

\begin{tabular}{|l|l|r|r|r|r|}
\hline Dönem 3 & $03.1995-10.2004$ & 125 & 0.076 & 0.126 & $6.765^{* * *}$ \\
\hline Dönem 4 & $10.1995-05.2006$ & 125 & 0.072 & 0.116 & $7.009 * * *$ \\
\hline Dönem 5 & $11.1996-06.2007$ & 125 & 0.069 & 0.112 & $6.862 * * *$ \\
\hline Dönem 6 & $09.1997-07.2010$ & 125 & 0.073 & 0.109 & $7.490 * * *$ \\
\hline Dönem 7 & $06.1998-02.2011$ & 125 & 0.073 & 0.110 & $7.443 * * *$ \\
\hline Dönem 8 & $12.1999-07.2011$ & 125 & 0.069 & 0.106 & $7.236 * * *$ \\
\hline Dönem 9 & $05.2000-05.2012$ & 125 & 0.060 & 0.104 & $6.480 * * *$ \\
\hline Dönem 10 & $11.2000-11.2014$ & 125 & 0.059 & 0.103 & $6.389 * * *$ \\
\hline Dönem 11 & $02.2002-05.2015$ & 125 & 0.059 & 0.102 & $6.506 * * *$ \\
\hline
\end{tabular}

$\% 1, \% 5$ ve $\% 10$ düzeyinde istatistiksel anlamlılık, sirasıly ***, ** ve * ile gösterilmiştir.

Tablo 6'da da görülebileceği gibi araştırma dönemimizin başındaki 125 ilk halka arz için ortalama anormal getiri \%8.8 iken bu getirinin yıllar itibariyle düştüğü ve 02.2002-05.2015 dönemini kapsayan 125 şirketlik örneklem için \%5.9 olarak gerçekleştiği tespit edilmiştir. Tüm örneklemler için ilk gün anormal getirilerin istatistiksel olarak sıfirdan farklı olmasına rağmen yaşanılan bu düşüş oldukça dikkat çekicidir. Ortalamalardaki düşüşün yanında standart sapmalardaki düşüşün de dikkate değer olduğu düşünülmektedir. İlk grup ve son grup arasında ortalama anormal getirilerin istatistiksel olarak anlamlı olup olmadığı bağımsız örneklem t testi ile analiz edilmiş ve sonuçlar Tablo 7'de raporlanmıştır.

Tablo 7: Bă̆ımsız Örneklem T Testi Sonuçları

\begin{tabular}{|l|r|r|r|r|}
\hline Dönem & $\mathrm{N}$ & Ortalama & Std. Sapma & t-ist. \\
\hline $02.1993-07.2000$ & 125 & 0.088 & 0.132 & \multirow{2}{*}{$1.955^{*}$} \\
\cline { 1 - 4 } $02.2002-05.2015$ & 125 & 0.059 & 0.102 & \\
\hline
\end{tabular}
gösterilmiştir.

Tablo 7'den de görülebileceği gibi araştırma döneminin başındaki halka arzlarda elde edilen ilk gün anormal getiri ile araştırma döneminin son kısmını kapsayan halka arzlarda elde edilen ilk gün anormal getiri arasında \%10 düzeyinde istatistiksel olarak anlamlı fark bulunmaktadır. Bu sonuç halka arz ortamında yaşanılan gelişmelerin düşük fiyatlama seviyesini azalttığını ancak düşük fiyatlamanın halen devam ettiğini göstermektedir.

\section{Sonuçlar}

Pay senetlerinin halka arz fiyatı ile ikincil piyasadaki ilk işlem günü oluşan fiyat arasındaki farka göre risk priminin de dikkate alınması yoluyla hesaplanan düşük fiyatlamanın varlığı birçok ülkede test edilmiş ve genel olarak piyasalarda ilk halka arzda düşük fiyatlamanın varlı̆ğ ile ilgili bulgular elde edilmiştir. Buna göre ilk halka arz fiyatından pay senedine yatırım yapan yatırımcı halka arzdan sonra borsada pay senedinin işlem görmeye başlaması ile artan fiyattan yararlanarak anormal getiri elde edebilmektedir. Anormal getirinin büyüklüğü ve ne kadar süre ile anormal getiri elde edilebileceği sorusuna cevap arayan çalışmalardan elde edilen sonuçlar karşılaştırıldığında ülkelere göre, örneklem döneminin seçimine göre veya 
İlk Halka Arzda Düşük Fiyatlama Seviyesi Zamanla Değişiyor Mu? Borsa İstanbul Üzerine Bir Araştırma

örneklemde kullanılan şirket sayısına göre anormal getirilerin değişebildiği görülmektedir.

Çalışmamızda ilk işlem gününden itibaren 20 işlem gününü kapsayan kısa dönem perspektifinden Borsa İstanbul'da anormal getirinin varllğ 1 ve büyüklüğü test edilmiştir. Analize dâhil edilen şirket sayısının artışı, yapılan istatistiki testlerden elde edilen sonuçların güvenilirliğini de artıracaktır. Anormal getiri, piyasa getirisine göre düzeltilmiş ve piyasa modeli kullanılarak düzeltilmiş getiri şeklinde hesaplanmıştır. Böylece anormal getirinin farklı hesaplama yöntemlerine duyarlılığ araştırılmıştır. Çalışmada ayrıca hareketli ortalama esasına göre farklı dönemleri yansıtan eşit sayıda portföyler oluşturularak zaman içerisinde anormal getirinin değişip değişmediği, diğer bir ifade ile sermaye piyasalarında yaşanan gelişme seyrinin anormal getiri üzerinde etkisinin olup olmadığı incelenmiştir.

320 şirketten oluşan veri seti için hesaplanan anormal getiriler $\left(\mathrm{AR}_{T}\right.$ ve $\left.A R_{D}\right)$ ve ayrica 265 şirket için hesaplanan anormal getirilerin $\left(A R_{T}, A_{D}\right.$ ve $\left.A R_{P}\right)$ tümü istatistiksel açıdan \%1 anlamlılık düzeyinde sıfırdan farklı bulunmuştur. Örneğin ilk gün getirisinden ilk işlem günü piyasa getirisinin çıkarılması ile elde edilen ilk gün düzeltilmiş anormal getiri \% 7.3, piyasa modeline göre hesaplanan anormal getiri ise \% 7.2'dir. Elde edilen sonuçlar halka açılan şirketlerde düşük fiyatlamanın güçlü bir şekilde varlığına işaret etmektedir. Reel sektör şirketleri ve mali sektör şirketleri açısından yapılan analizde düşük fiyatlama olgusunun sektörel açıdan farklılaşmadığı ve her iki grup için de geçerli olduğu görülmektedir. Beşinci gün ve sonrasında yirminci güne kadar olan on altı günlük sürenin on bir gününde negatif getirinin ortaya çıktığı ve bu getirilerin bir bölümünün de istatistiksel olarak anlamlı olduğu tespit edilmiştir. Örneğin ilk üç gün için hesaplanan kümülatif anormal getiri \%10.2 iken daha sonra bu getirinin düşüş eğilimine girdiği ve yirmi günlük sürede $\% 8.4$ 'e gerilediği görülmektedir. Özellikle 5 . ve 15 . günler arasında ortaya çıkan kümülatif anormal getiri negatif ve istatistiksel açıdan anlamlıdır. Anormal getirideki bu seyir ilk üç günde ortaya çıan anormal getirinin daha sonra yatırımcılar tarafından realize edildiğini göstermektedir.

Çalışmada ayrıca zaman içerisinde düşük fiyatlama düzeyinin azaldığı ancak halen istatistiksel olarak anlamlı bir düşük fiyatlamanın devam ettiği tespit edilmiştir. Şirketler halka arz tarihlerine göre sıralanmış ve 125 'er şirketten oluşan örneklemler için hareketli ortalama esasına göre anormal getiriler hesaplanmıştır. Buna göre birinci grubu oluşturan Şubat 1993 ile Temmuz 2000 arasında halka arzı gerçekleşen 125 şirket için anormal getiri \% 8.8 iken zamanla bu getirinin azaldığ 1 ve son grubu oluşturan Şubat 2002 ile Mayıs 2015 arasında halka arzı gerçekleşen 125 şirket için anormal getiri \% 5.9 olarak gerçekleştiği tespit edilmiş ve bu iki grup ortalamaları arasındaki farkın istatistiksel açıdan anlamlı olduğu görülmüştür. Araştırma dönemi boyunca halka arz ortamında yaşanılan gelişmeler diğer bir ifade ile halka arzın tarafları olan aracı kurumlar, yatırımcılar ve halka arz edilen şirketlerin halka arz ile ilgili bilgi ve deneyimlerinin artması, halka arz süreçlerinde yaşanan gelişmeler, finansal piyasalar ve makroekonomik şartlarda yaşanan 
gelişmeler düşük fiyatlama seviyesini azaltmıştır. Ancak ilk halka arzda düşük fiyatlama halen devam etmektedir.

\section{Kaynaklar}

Aggarwal, R. (2000). Stabilization Activities by Underwriters After Initial Public Offerings, The Journal of Finance, 55(3), 1075-1104.

Aggarwal, R., Leal, R., Hernandez, L. (1993). The Aftermarket Performance of Initial Offerings in Latin America, Financial Management Association International, 22(1), 42-53.

Aggarwal, R., Rivol1, P. (1990). Fads in the Initial Public Offering Market?, Financial Management Association International, 19(4), 45-57.

Aktaş, R., Karan, M. B., Aydoğan, K. (2003). Forecasting Short Run Performance of Initial Public Offerings in The Istanbul Stock Exchange, The Journal of Entrepreneurial Finance, 8(1), 69-85.

Allen, F., Faulhaber, G. R. (1989). Signaling by Underpricing in the IPO Market, Journal of Financial Economics, 23, 303-323.

Baron, D. P. (1982). A Model of the Demand for Investment Banking Advising and Distribution Services for New Issues, The Journal of Finance, 37(4), 955976.

Barry, C. B., Jennings, R. H. (1993). The Opening Price Performance of Initial Public Offerings of Common Stock, Financial Management, 22(1), 54-63.

Bildik, R., Y1lmaz, M. K. (2008). The Market Performance of Initial Public Offerings in the Istanbul Stock Exchange, BDDK Bankactlik ve Finansal Piyasalar, 2(2), 49-76.

Booth, J. R., Smith, R. L. (1986). Capital Raising, Underwriting and The Certification Hypothesis, Journal of Financial Economics, 15, 261-281.

Boulton, T. J., Smart, S. B., Zutter, C. J. (2013). Industrial Diversification and Underpricing of Initial Public Offerings, Financial Management, 42(3), 679704.

Carter, R., Manaster, S. (1990). Initial Public Offerings and Underwriter Reputation, Journal of Finance, 45(4), 1045-1067.

Chahine, S. (2002). Mispricing in IPO Methods and the Predictive Ability of Investors' Interest for New Issues, University of Audencia-Nantes, Working Paper.

Chemmanur, T. J., Hu, G., Huang, J. (2010). The Role of Institutional Investors in Initial Public Offerings, Review of Financial Studies, 23(12), 4496-4540.

Chiang, Y., Hirshleifer, D., Qian, Y., Sherman, A. E. (2011). Do Inverstors Learn From Experince? Evidence from Frequent IPO Investors, The Review of Financial Studies, 24(5), 1560-1589.

Dağlı, H., Kurtaran, A. (2008). İlk Halka Arzlarda Düşük Fiyatlandırmayı Etkileyen Unsurlar: Türkiye Örneği, Muhasebe ve Finansman Dergisi, 39, 58-66.

Dell'acqua, A., Etro, L., Teti, E., Murri, M. (2015). IPO underpricing and Aftermarket Performance in Italy, Journal of Economic and Financial Studies, 3(3), 1-14. 
Ilk Halka Arzda Düşük Fiyatlama Seviyesi Zamanla Değişiyor Mu? Borsa İstanbul Üzerine Bir Araştırma

Durukan, B. M. (2002). The Relationship Between IPO Returns and Factors Influencing IPO Performance: Case of Istanbul Stock Exchange, Managerial Finance, 28(2), 18-38.

Elmas, B. (2013). Halka Açılan Şirketlerin Hisse Senetlerinde Alım-Satım Yoluyla Kazanç Elde Edilebilir mi? BİST'den Deliller, Maliye ve Finans Yazıları Dergisi, 99, 39-58.

Giudici, G., Paleari, S. (2001). The Market Performance of Italian IPOs in the LongRun, 8th Asia Pacific Finance Association Annual Conference, Working Paper.

Ibbotson, R. G., Sindelar, J. L., Ritter, J. R. (1988). Initial Public Offerings, Journal of Applied Corporate Finance, 1(2), 37-45.

Kaya, T. (2012). The Short Term Performance of Initial Public Offerings in Istanbul Stock Exchange: 2010-2011 Application, Journal of Business, Economics and Finance, 1(1), 64-76.

Kırkulak, B. (2010). Uzun Dönemli Al ve Tut Getirileri: İMKB'de Halka Açık Şirketler Üzerine Bir Uygulama, Ege Akademik Bakış Dergisi, 10(2), 465486.

Kıymaz, H. (1996). Halka İlk Arz Edilen Hisse Senetlerinin Performansları: İmalat Sektörü 1990-1995 Uygulaması, İşletme ve Finans Dergisi, 3, 121-143.

Kiymaz, H. (2000). The Initial and Aftermarket Performance of IPOs in an Emerging Market: Evidence From Istanbul Stock Exchange, Journal of Multinational Financial Management, 10, 213-227.

Kocaman, B. (1995). Hisse Senetlerinin İlk Halka Arzında Düşük Fiyatlandırma, $і \ddot{I}$ Siyasal Bilgiler Fakültesi Dergisi, 11-12-13, 199-207.

Kooli, M., Suret, J. M. (2004). The Aftermarket Performance of Initial Public Offerings in Canada, Journal of Multinational Financial Management, 14(1), 47-66.

Kurtaran, A. (2008). İlk Halka Arzlardaki Düşük Fiyatlandırmanın İstanbul Menkul Kıymetler Borsasında Değerlendirilmesi, Íktisadi ve İdari Bilimler Dergisi, 22(1), 407-419.

Kurtaran, A. (2013). Türkiye'deki İlk Halka Arzların İlk Getirileri İle Uzun Dönem Fiyat Performansları Arasındaki İlişkinin Analizi, Uluslararası İktisadi ve Idari Incelemeler Dergisi, 6(11), 185-210.

Küçükkocaoğlu, G., Alagöz, A. (2009). İMKB' de Uygulanan Halka Arz Yöntemlerinin Karşılaştırmalı Analizi, Dokuz Eylül Üniversitesi İktisadi ve Idari Bilimler Fakültesi Dergisi, 24(2), 65-86.

Ljungqvist, A. P. (1997). Pricing Initial Public Offerings: Further Evidence from Germany, European Economic Review, 41(7), 1309-1320.

Ljungqvist, A. P., Jenkinson, T., Wilhelm, W. J. (2000). Has the Introduction of Bookbuilding Increased the Efficiency of International IPOs?, Working Paper.

Logue, D. E. (1973). On the Pricing of Unseasoned Equity Issues: 1965-1969, Journal of Financial and Quantitative Analysis, 8(1), 91-103. 
Michaely, R., Shaw, W. H. (1994). The Pricing of Initial Public Offerings: Tests of Adverse-Selection and Signaling Theories, The Review of Financial Studies, 7(2), 279-319.

Miloud, T. (2014). Earnings Management and Initial Public Offerings: An Empirical Analysis, The Journal of Applied Business Research, 30(1), 117-134.

Oran Sözer, J., Aytürk, Y., Akbaba, C. (2013). İlk Halka Arz Bilmecesi: Türk Sermaye Piyasasından Güncel Bulgular, Bankacılık Dergisi, 87, 79-98.

Otlu, F., Ölmez, S. (2011). Halka İlk Kez Arz Edilen Hisse Senetlerinin Kısa Dönem Fiyat Performansları ile Fiyat Performanslarını Etkileyen Faktörlerin İncelenmesi, İKMB'de Bir Uygulama, Akademik Yaklaşımlar Dergisi, 2(2), 14-44.

Pham, P. K., Kaley, P. S., Steen, A. B. (2003). Underpricing, Stock Allocation, Ownership Structure and Post-Listing Liquidity of Newly Listed Firms, Journal of Banking and Finance, 27(5), 1-33.

Ritter, J. R. (1984). The Hot Issue Market of 1980, Journal of Business, 57(2), 215240.

Ritter, J. R. (1991). The Long-Run Performance of Initial Public Offerings, Journal of Finance, 46(1), 3-27.

Ritter, J. R., Welch, I. (2002). A Review of IPO Activity, Pricing, and Allocations, The Journal of Finance, 57(4), 1795-1828.

Rock, K. (1986). Why New Issues are Underpriced, Journal of Financial Economics, $15,187-212$.

Sağlam, G. Y., Çelik, A. E. (2011). İstanbul Menkul Kıymetler Borsası'nda Düşük Fiyatlandırma ve Aracılık Türü, Arz Y111, Aracı Kurum Etkileri Üzerine Bir Araştırma, Doğuş Üniversitesi Dergisi, 12(2), 289-303.

Teker, S., Ekit, Ö. (2003). The Performance of IPOs in Istanbul Stock Exchange in Year 2000, Doğuş Üniversitesi Dergisi, 4(1), 117-128.

Tınıç, S. M. (1988). Anatomy of Initial Public Offerings of Common Stock, The Journal of Finance, 43(4), 789-822.

Tükel, A. (2010). Asimetrik Enformasyon Işığında Halka Arzların Uzun Dönemli Performanslarının Değerlendirilmesi, Ekonometri ve İstatistik Dergisi, 12, 102-121.

Ünlü, U., Ersoy, E. (2008). İlk Halka Arzlarda Düşük Fiyatlama ve Kısa Dönem Performansın Belirleyicileri: 1995-2008 İMKB Örneği, Dokuz Eylül Üniversitesi İktisadi ve İdari Bilimler Fakültesi Dergisi, 23(2), 243-258.

Yalçıner, K. (2006). Düşük Fiyatlama Olgusu ile Halka Arz Şekilleri ve Halka Arz Fiyatı Arasındaki İlişkinin Analizi: 1997-2004 Dönemine Ait Bir İnceleme, Gazi Üniversitesi İktisadi ve İdari Bilimler Fakültesi Dergisi, 7(2), 145-158.

Zarafat, H. (2013). Performance of Initial Public Offerings: An Empirical Study, The International Journal of Finance, 25(4), 8013-8034.

Zhou, Z. (2014). Opening-Price Performance of Initial Public Offerings in China, Chinese Economy, 47(2), 94-109. 